\title{
A perspective on emerging mosquito and phlebotomine- borne diseases in Europe
}

G Hendrickx (info@avia-gis.be) ${ }^{1}$, R Lancelot ${ }^{2}$

1. Avia-GIS, Agro-Veterinary Information and Analysis, Zoersel, Belgium

2. CIRAD, French Agricultural Research Centre for International Development, UMR CMAEE (Control of emerging and exotic animal diseases), Montpellier, France

Citation style for this article:

Citation style for this article: Hendrickx G, Lancelot R. A perspective on emerging mosquito and phlebotomine-borne diseases in Europe. Euro Surveill. 2010;15(10):pii=19503. Available online: http://www.eurosurveillance.org/ViewArticle.aspx?Articleld=19503

This article has been published on 11 March 2010

Emerging infectious diseases are of increasing concern worldwide and in particular in Europe. In a review, Jones et al. have shown that between 1940 and 2004, the majority of emerging infectious diseases occurred in areas with both a high mobility and high density of population, notably in Western Europe. Furthermore, nearly a third (29\%) of the recorded events related to emerging infectious diseases were due to vector-borne diseases during the decade 1990-2000[1].

This issue of Eurosurveillance presents a series of review articles with a particular focus on arthropodborne diseases transmitted by mosquitoes and phlebotomine sandflies. Each of the papers addresses a series of issues of common interest such as the relevance of the disease in the given context, its transmission and epidemiology, including the current geographical distribution, and clinical symptoms, diagnostic methods, treatment strategies and prevention methods. Furthermore, the papers describe factors triggering changes in distribution of the vectors and disease and risk prediction models.

A review on West Nile virus by Reiter includes a fresh and innovative viewpoint on the epidemiology and transmission of the disease [2], and the same author contributed further with a twin-review on two diseases which have much in common: yellow fever and dengue [3]. Most importantly, both have a history of occurrence in Europe and vectors and pathogens are spreading through increased movement of persons and transport of goods. Chevalier et al. present a review on Rift Valley fever a mosquito-borne disease at Europe's fringes. The epidemiology of Rift Valley fever is fascinating because of its complex cycle where the virus may remain dormant for many years and outbreaks involve both vector related and direct transmission. The disease may become a risk in the future in countries bordering the Mediterranean Sea, mainly through increased livestock trade.

Two authors have contributed reviews on viruses transmitted by phlebotomine sandflies. Ready has written about Leishmania, a parasite of particular relevance to Europe because it is currently established around the Mediterranean Sea, but known to be spreading north [4]. Depaquit et al. have contributed a review on a number of less well known Phlebo-, Vesiculo- and Orbiviruses such as Sandfly fever Sicilian and Naples virus, Toscana virus Chandipura virus and others that are transmitted by sandflies in Europe and more specifically around the Mediterranean Sea [5]. The paper summarizes the current knowledge on these viruses which have a potential to spread throughout the distribution zone of their phlebotomine vectors in Europe. Both reviews provide a series of maps displaying country based information on the distribution of the disease.

In addition to these papers, the issue features a perspective paper by Maltezou et al. presenting the present situation of Crimean-Congo hemorrhagic fever, a tick-borne disease, in Europe and emphasizing relevant aspects for preparedness concerning the potential spread of this disease in Europe in the future [6].

As will become clear from reading these reviews, often crucial knowledge is still missing which is needed to anticipate, prevent or prepare for the establishment and spread of vector-borne diseases. One of these is reliable information on the continent wide distribution of potential disease vectors. National presenceabsence maps, as shown by Ready [4] and Depaquit [5] are a first step in this direction and need further refinement.

In 2007-08, the European Centre for Disease Prevention and Control funded the V-borne project with the aim to identify and document vector-borne diseases relevant for public health in Europe, provide an overview of the existing relevant resources, carry out a qualitative multi-disciplinary risk assessment within the limits of the available information and data, and identify priorities for future prevention and control of vector borne diseases in Europe. Building on the expertise from this network, ECDC created a European network for 
arthropod vector surveillance for human public health, the VBORNET in 2009 [7]. The network will establish pan-European state of the art maps of validated vector distributions that can be used as basis for risk assessment studies thus contributing to preparedness for the emerge or re-emerge of vector-borne disease in Europe.

\section{References}

1. Jones KE, Pate NG, Levy MA, Storeygard A, Balk D, Gittleman $J \mathrm{~L}$ et al. Global trends in emerging infectious diseases. Nature. 2008;451:990-3. Available from: http://dx.doi.org/10.1038/ nature06536

2. Reiter P. West Nile virus in Europe: understanding the present to gauge the future. Euro Surveill. 2010;15(10):pii=19508. Available from: http://www.eurosurveillance.org/ViewArticle. aspx?Articleld $=19508$

3. Paul Reiter Dengue and Yellow fever Eurosurveillance. Euro Surveill. 2010;15(10):pii=19509. Available online: http://www. eurosurveillance.org/ViewArticle.aspx?Articleld=19509

4. Chevalier V, Pépin M, Plée L, Lancelot R. Rift Valley fever - a threat for Europe?. Euro Surveill. 2010;15(10):pii=19506. Available from: http://www.eurosurveillance.org/ViewArticle. aspx?Articleld=19506

5. Depaquit J, Grandadam M, Fouque F, Andry P, Peyrefitte C. Arthropod-borne viruses transmitted by Phlebotomine sandflies in Europe: a review . Euro Surveill. 2010;15(10):pii=19507. Available from: http://www. eurosurveillance.org/ViewArticle.aspx?Articleld=19507

6. Maltezou HC, Andonova L, Andraghetti R, Bouloy M, Ergonul O, Jongejan F, Kalvatchev N, Nichol S, Niedrig M, Platonov A Thomson G, Leitmeyer K, Zeller H. Crimean-Congo hemorrhagic fever in Europe: current situation calls for preparedness. Euro Surveill. 2010;15(10):pii=19504. Available online: http://www. eurosurveillance.org/ViewArticle.aspx?Articleld =19504

7. European Centre for Disease prevention and Control (ECDC). Network of medical entomologists and public health experts (VBORNET). Available from: http://www.ecdc.europa.eu/en/ activities/diseaseprogrammes/Pages/VBORNET.aspx 